\title{
The integration of AHP and QFD for contractors selection
}

\author{
Briliantie Irma ${ }^{1 *}$, Imam Baihaqi ${ }^{2}$ \\ ${ }^{1}$ Department Of Magister Manajemen of Technology, Sepuluh Nopember Institute of Technology, Surabaya, Indonesia \\ ${ }^{2}$ Department of Business and Management, Sepuluh Nopember Institute of Technology, Surabaya, Indonesia
}

\author{
Keywords \\ Analytical hierarchy process \\ Quality function deployment \\ House of quality \\ Tender slection \\ Contractor
}

Received: 11 April 2018

Accepted: 18 May 2018

Published: 12 June 2018

\begin{abstract}
Procurement of Government Goods/Services has an important role in the realization of national development to improve public services and the development of the national economy. Implementation of contractor tender selection by the Government Procurement Service Unit must be implemented quickly and produce effective decisions. Usually, a decision of Working Group Selection is not following the wishes of the Project Owner, and Project Owner needs contractors who can fulfill the specifications, have a correct methodology, have sufficient workers, have reasonable prices, and complete on time. This research was conducted to develop a method of selecting contractors by integrating the AHP and QFD. The result of this research is an application that can be used as tools selection. This application contains "Voice of Owner," which is calculated using the AHP, and weights of technical responses are modeled with HOQ. Fifty priority technical responses must be fulfilled by the Working Group when doing the contractor evaluation. It is expected that these applications will help the Working Group select contractors according to the wishes of the owner.
\end{abstract}

(C) 2018 The Author(s). Published by TAF Publishing.

\section{INTRODUCTION}

Realizing integrated and efficient city infrastructure and utilities is one of goverment's vision and mission. The construction of the city's infrastructure is inseparable from the relevant agencies whose task is to prepare the facilities and infrastructure. The results of integrated infrastructure development will provide maximum benefits to the people.

To ensure the implementation of the procurement of goods/services to be more integrated in accordance with the objectives, policies, principles and ethics of government goods/services procurement, as well as to increase effectiveness and efficiency in carrying out the duties and functions of regional government, the regional government is obliged to establish a Goods/Services Procurement Unit which has a strategic, collaborative, performance-oriented, proactive and capable of continuous improvement so as to encourage the creation of added value and benefits in the procurement of goods/services in Indonesia.

The process of procurement of goods services is a very important and crucial process, because it involves many peo- ple, many contractors, carried out in a limited time and produce the right decisions. To make a correct decision making with many criteria and different decision makers backgrounds a decisions support system is needed. For this reason, this study was conducted to determine the decision making process of the winner of the tender conducted by the working group within the government accordance with the rules expected by the project owner. This research involved existing project owners within the government and work groups for the procurement of goods/services in the Government Procurement Service Unit.

A working group is a human resource assigned by a head master of Government Procurement Service Unit to manage the selection of contractor. The construction working group involved 18 working groups consisting of at least three members of the election with the adhoc status. Adhoc status is the status in which the working group members are representatives from every department in the government. The backgrounds of working group members who come from different agencies, with different experience and

\footnotetext{
${ }^{*}$ Corresponding author: Briliantie Irma

†email: briliantie2012@gmail.com
} 
knowledge of the construction work handled, make decisions that are taken sometimes not as expected as the project owner. On the other hand the crucial process of a project is to select contractors who can complete the project according to demand $[1,2,3]$. [4] conducted a study of several decision-making methods used in the process of selecting contractors. From the results of the study, it was concluded that the method used in the contractor selection process must be able to meet the specific characteristics of the contractor selection process to get the best evaluation results. The amount of work that must be dismantled (reject), and repeated (rework) will increase the delay of the project (overruns), resulting in quality that does not comply with the specifications expected, errors contractor selection will also make accidents, disputes, and failure [5].

The most frequently complained by the Project Owner (PO) when finding contractors who did not comply with Project Onwer request was when the working group won the contractor with a very low bid price (below $80 \%$ of the total estimated price). The often encountered rejects, reworks and overruns by $\mathrm{PO}$ are construction work packages with values below Rp. 100 Billion which is using the lowest bid price evaluation method with a knockout system. This research was conducted to find out the evaluation model of effective construction service providers to produce efficient, integrated and targeted decisions between the working group and $\mathrm{PO}$ in the selection of construction service provider regardless of the applicable regulations which are transparent, efficient, effective, corruption free.

The understanding of the working group as the determinant of the project contractor to identify owner needs is important for the success of the project, therefore it is necessary to integrate the voice of the Owner against the contractor selection requirements. In order to translate the "voice" of Owner into contractor selection requirements, the author uses QFD combined with AHP. This theory is based on opinions from [6] which states that the AHP which integrate with QFD is used to help decision makers to prioritize, where AHP-QFD is a promising method to consider the "voice" of corporate stakeholders and integrate them in the sustainability of the supplier selection.

Difficulties that exist in QFD according to [7] is the difficulty in translating customer voices. Complexity in QFD is the number of problems that must be considered because translating the "voice" of the customer is an assessment of the many trade-offs faced [6]. The traditional QFD approach uses the importance of absolute value to identify the relative importance of each customer's needs, except that customers almost judge all criteria to be "important", so com- panies are forced to make trade-offs due to limited company resources [8]. Sometimes, some customer requirements conflict with their nature, such as the lowest cost versus the highest quality [9].

[10] also noted that the ranking of the importance of customer voices is generally determined by decision makers who can be carried out arbitrarily which can lead to a certain level of inconsistency and decrease the quality of decisions, resolving trade-offs is an important problem. AHP is a method that can be used to reconcile differences (inconsistencies) in managerial assessment and perception, AHP is better at completing trade-offs. AHP applies decisions as a system so that it can help decision makers to take the best steps in regulating their minds [9]. Therefore in this research, a study was proposed by combining AHP and QFD for the selection of Contractors, where AHP helped develop the quality matrix stages that exist in QFD.

Comprehensive literature studies have been conducted by [11] showing that the combined AHP approach-QFD has been applied to various situations, including selection of Education requirements, teaching selection methods, product design selection, capital budget project selection, location facility selection, robot selection and selection of fast tooling processes $[12,13]$.

In the QFD process, a matrix called HOQ is used to display the relationship between customer voices called "WHATS" and quality characteristics called "HOW". Although the main functions of QFD are product development, quality management, and customer needs analysis, QFD functions have been extended to broader fields such as strategy development, planning, design, engineering, management and supplier evaluation and selection $[7,14]$.

The AHP combined with QFD is a popular approach that is often used to determine the relative importance of the customer, combined AHP and QFD are used in journals (Olivier, Bor The integration of AHP-QFD in this study was conducted to find the best solutions by decision makers in complex problems using systematic and hierarchical networks in various levels and criteria [6, 15]. Integrating AHP - QFD in this study was conducted to find the best solution by decision-makers in complex problems using a systematic and hierarchical networks in a variety of levels and criteria.

The purpose of this study is to formulate a model of contractor selection decision-making system that produces a suitable provider with the wishes of the Project Owner as "customer" and the principles of procurement that is efficient, effective, transparent, open, competitive, fair and accountable. The rest of he papaer we will discuss the research 
methodology in chapter 2 , discussion and results in chapter 3 , case studies in chapter 4 and conclusions in chapter

\section{RESEARCH METHODE}

\section{A. AHP}

AHP is a Multi Criteria Decision Making (MCDM) model in the decision-making process developed by [16]. This model decision-making process will describe multi-factor problems or complex multi criteria into a hierarchy. [16] states that hierarchy is defined as a representation of a complex problem in a multi-level structure where the first level is the goal, followed by the level of factors, criteria, sub criteria, and so on to the last level of the alternative.

With hierarchy, a complex problem can be broken down into groups which are then arranged as a form of hierarchy so that problems appear to be more structured and systematic. The AHP developed by Saaty can solve complex problems where the criteria taken are quite large. Also this complex- ity is caused by the structure of the problem that is not yet clear, the uncertainty of the perceptions of decision makers and the uncertainty of the availability of accurate or even nonexistent statistical data [17]. Referring to the theory developed by [16] about AHP through [18], that AHP provides a means to discuss the problem into the sub-problems hierarchy in order to be more easily understood and evaluated subjectively. The AHP methodology can be explained in the following steps:

1) Step 1: The problem is decomposed into a hierarchy of goals, criteria, and alternatives. Decision making is fundamental to the AHP process. The hierarchy shows the relationship between elements, reaching the lowest hierarchy level. Saaty argues that a useful way to compile a hierarchy is to work down from the target and then work from the alternative to the second level of the process that is linked in such a way as to be a comparison between possible criteria. Figure 1 Shows the hierarchical structure of the AHP concept adapted for this study.

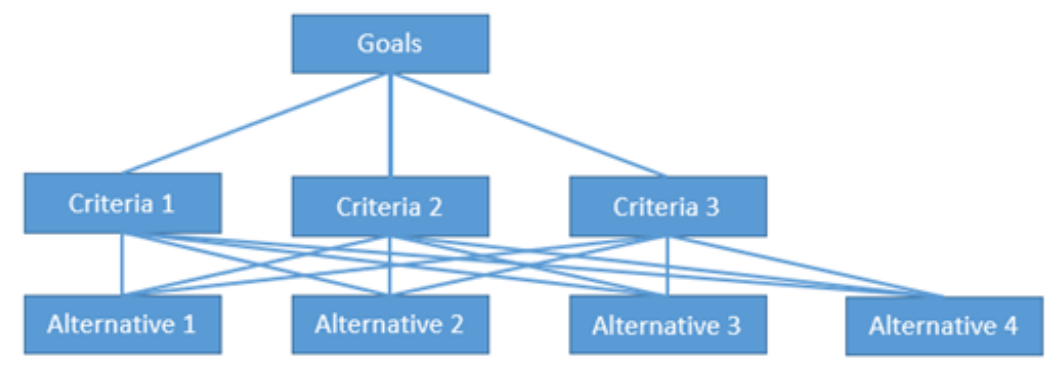

Fig. 1. Hierachical structure of the AHP soncept

2) Step 2: Data is collected from experts or decision makers in accordance with a hierarchical structure, in an alternative comparison in pairs with a qualitative scale by as- sessing the comparison as the equal important, Moderately more important, strongly more important, very strongly important and Extremely more important.

TABLE 1

THE NUMERICAL ASSESSMENT AND LINGUISTIC MEANING

\begin{tabular}{ll}
\hline \hline Numerical Assessment & Linguistic Meaning \\
\hline 1 & Equal important \\
3 & Moderately more important \\
5 & Strongly more important \\
7 & Very strongly important \\
9 & Extremely more important \\
$2,4,6,8$ & Intermediate values of importance \\
\hline \hline Resources: $[19]$ &
\end{tabular}

3) Step 3: Pairwise comparisons of the various criteria produced in step 2 are arranged into square matrices. The diagonal element of the matrix is 1 . The criteria in line $i$ are better than the criteria in the $j$-column if the element value $(i, j)$ is more than 1 . If not, the criteria in column $\mathrm{j}$ are better than row $i-i$. Element $(j, i)$ is the opposite of element $(i, j)$

4) Step 4: The main eigenvalues and right eigenvectors normalized from the comparison matrix give the relative 
importance of the various criteria compared. Elements of a normalized eigenvector are called weights with criteria and sub criteria and judgments with respect to the alternatives. 5) Step 5: The consistency of the n-sequence matrix is evaluated. If this consistency index fails to reach the required level, the answers to comparisons can be reexamined. Consistency index, CI (Consistency Index), calculated by the formula:

$$
C I=(\lambda \max -n)-(n-1)
$$

Where $\lambda \max$ is the maximum eigenvalue of the assessment matrix. This CI can be compared to a random matrix, RI (Ratio Index). The reduced ratio, CI/RI, is called the consistency ratio, CR. Saaty suggests that the CR value must be less than 0.1 .

6) Step 6: The rating of each alternative is multiplied by the weight of the sub criteria and is collected to get a local rating with respect to each criterion. Local ratings are then multiplied by the criteria weight and combined to get a global ranking. AHP produces weight values for each alternative based on judgments judged from one alternative above the other with regard to general criteria.

\section{B. QFD}

QFD is a method used to determine the priority needs and desires of consumers and group them. QFD can be used both for companies that offer products or services for con- sumers. QFD is known as a system created to translate customer requests into products that are compliant with new technical requirements or service services. QFD originated in Japan in the late 1960s and early 1970s [14]. QFD according to $[20,21]$ is a method used to determine consumer desires by collecting customer voices and customer needs. Both of these are then classified and sorted by priority. The QFD process can involve one or more matrices.

\section{HOQ}

According to [22] HOQ is the central nerve that moves the entire QFD process. There are many different forms of House of Quality, but its ability to adapt to requirements from special problems makes it a very strong and reliable system. This includes customer needs, technical requirements, planning matrix, linkages to matrices, technical matrix correlations, priorities/benchmarks and technical targets.

According to [23], HOQ shows the structure to design and form a cycle and its shape resembles a key house. The application of the QFD Method, will begin with making a matrix called HOQ. 6 steps ini House of Quality:

\section{Section (1): Customer Requirements}

Is a matrix of customer needs and benefits This matrix contains consumer needs which are often called Voice of Costumers.

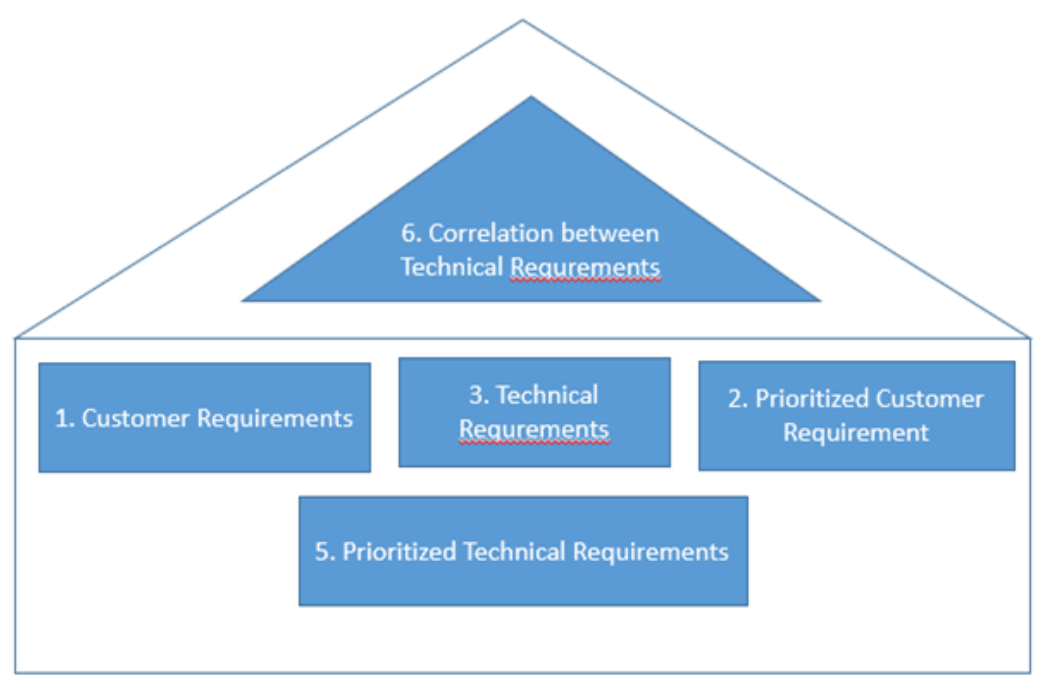

Fig. 2. Stages of HOQ

\section{Section (2): Prioritized Customer Requirements}

Is a matrix that is used to translate the needs of consumers.

3. Section (3), The Technical Characteristics Matrix/Substitute Quality Characteristics

This matrix makes technical characteristics which are parts where the company implements the mode that allows it to be realized in an effort to meet consumer needs.

4. Section (4), The relationship matrix

This matrix determines the VOC relationship with SQC and then translates it into a value that suggests the strength of 
the relationship (Impact).

5. Section (5), The correlation matrix of technical characteristics/Technical Correlation

That is the matrix which contains the linkages between one technical requirement and the other technical requirements contained in section $\mathrm{C}$.

6. Section (6), The Technical Matrix

The target for SQC is expressed as a function performance of SQC, which will be the target of development activities.

\section{RESULT AND DISCUSSION}

This chapter will briefly discuss the description of the explanation of the research methodology based on the framework of thinking and literature review. In general, this research is a qualitative study with a descriptive approach, with sampling techniques through interviews and question- naires and observations. Broadly speaking and concisely the author formulates the concept and method of this research as seen in the flow diagram.

\section{A. Project Owner Needs}

This study examines the desires/needs of Project Owner for the Public Works Office of Highways and Drainage in Surabaya City's Goverment. This research was carried out by conducting brainstorming with Project owner to find out whether this research was feasible to be appointed and obtain approval from the Project Owner needs. The results of the identification of project owner needs and the existing literature will be used as material by the author to carry out the next stage, namely the stages of distributing questionnaires to Project Owner and related stakeholders under Project Owner.

SAE-JAK

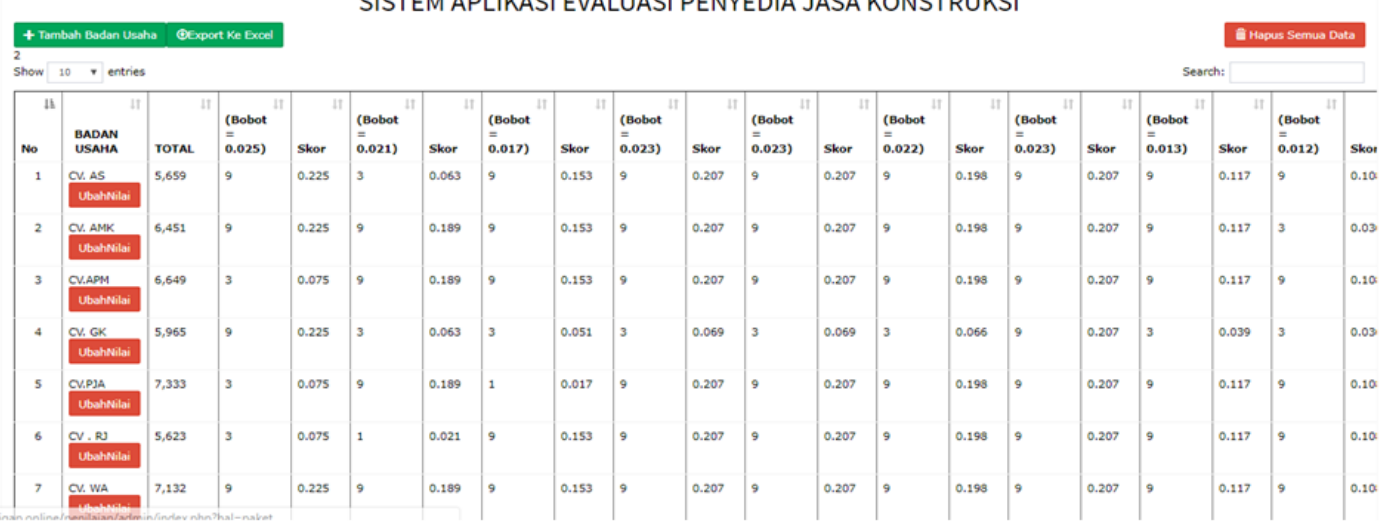

Fig. 3. Research method

\section{B. Distribution of Questionnaires to Project Owner and related Stakeholders}

The next stage after obtaining a list of criteria from the brainstorming/interviewing process with PO is to disseminate the questionnaire to the $\mathrm{PO}$ and related stakeholders, the distribution of the questionnaire is carried out by presenting a questionnaire list related to Project Owner Voice criteria.

The distribution of this questionnaire was carried out on 3 Project Owner and 45 technical and administrative staff owned by PO. The questionnaire distributed was carried out by the author himself, before the process of filling out the questionnaire was carried out a brief explanation to find out the purpose and objectives of the study so that accurate results were obtained at the interview. This questionnaire contains the voices of $\mathrm{PO}$ which will later be assessed for the weight of their interests, carried out by using the Saaty scale, by comparing 15 criteria that need to be assessed for the weight of the keys. The results of the calculations obtained in this stage, will later be used to determine the "Voice of Costumers" of PO.The results of weighting this assessment are carried out using AHP which will be explained in the process of making AHP in the Customer Requirement (CR).

\section{Determine Project Owner "VOC" to be a CR}

The results of the interviews obtained by the author were processed to classify the needs of each of the criteria further to be classified against each of the PPK needs. The thing that was produced in this process was the List of "Voice of Costumers" needed by PPK which would later be used as input as material for the Focus Group Discussion (FGD) on determining the Technical Response.

The "Voice of Customer" PPK obtained from the interviews of the three PPKs included: 
1. Bid at a fair price

2. Have good financial skills

3. Carry out work with the right job methodology

4. Carry out work in accordance with predetermined technical specifications

5. Having workforce in accordance with the needs of the project

6. Complete work on time

After the Analytical Hierarchy Process is carried out the weight of "Voice of Customer" is obtained as a Costumer Requirement.

\section{Pair-Wise Comparison Matrix}

At this stage the author will prioritize "Voice of Project Owner " through pair-wise comparison on AHP. Determination of this priority is carried out by conducting interviews using the AHP questionnaire using a scale [16]. The results of the questionnaire were then conducted by the FGD with the PO to assess whether the results of the assessment were in accordance with the wishes of PO. The results of the respondents then made a pairwise comparison matrix produced by tabulating the opinions of the respondents into a square matrix that compares each attribute into columns and rows.

TABLE 2

THE NUMERICAL ASSESTMENT AND LINGUISTIC MEANING

\begin{tabular}{|c|c|c|c|c|c|c|}
\hline $\begin{array}{l}\text { Voice of Project } \\
\text { Owner }\end{array}$ & $\begin{array}{l}\text { Bid at a fair } \\
\text { price }\end{array}$ & $\begin{array}{l}\text { Have good fi- } \\
\text { nancial skills }\end{array}$ & $\begin{array}{l}\text { Carry out } \\
\text { work with } \\
\text { the right job } \\
\text { methodology }\end{array}$ & $\begin{array}{l}\text { Carry out } \\
\text { work in } \\
\text { accordance } \\
\text { with pre- } \\
\text { determined } \\
\text { technical } \\
\text { specifica- } \\
\text { tions }\end{array}$ & $\begin{array}{l}\text { Having } \\
\text { workforce in } \\
\text { accordance } \\
\text { with the } \\
\text { needs of the } \\
\text { project }\end{array}$ & $\begin{array}{l}\text { Complete } \\
\text { work on time }\end{array}$ \\
\hline Bid at a fair price & 1 & 2 & 0,2 & 0.2 & 0,25 & 0.143 \\
\hline $\begin{array}{l}\text { Have good financial } \\
\text { skills }\end{array}$ & 0.5 & 1 & 0.333 & 0.2 & 0.333 & 0.2 \\
\hline $\begin{array}{l}\text { Carry out work } \\
\text { with the right job } \\
\text { methodology }\end{array}$ & 5 & 3 & 1 & 0.5 & 2 & 3 \\
\hline $\begin{array}{l}\text { Carry out work in } \\
\text { accordance with } \\
\text { predetermined } \\
\text { technical specifica- } \\
\text { tions }\end{array}$ & 5 & 5 & 2 & 1 & 3 & 4 \\
\hline $\begin{array}{l}\text { Having workforce in } \\
\text { accordance with the } \\
\text { needs of the project }\end{array}$ & 4 & 3 & 0.5 & 0.333 & 1 & 5 \\
\hline $\begin{array}{l}\text { Complete work on } \\
\text { time }\end{array}$ & 3 & 3 & 0.333 & 0.25 & 0.2 & 1 \\
\hline
\end{tabular}

\section{E. Normalization of Eigenvector Values and "Voice of Project Owner" Weight}

Normalization of the eigenvector value aims to get priority vector because from priority vector the weight value of the customer requirement is obtained. Priority vector and weight of customer requirements in this study can be seen in Table 2.

\section{F. Consistency Test of the "Voice of Project Owner"Weights}

Consistency of the decision hierarchy that has been produced, and compared to the consistency ratio in the consistency index, it is expected that the test results are not more than 0.1 so the resulting decision hierarchy weight is consistent/valid. 
TABLE 3

NORMALIZATION OF PAIRWISE COMPARISON MATRIX

\begin{tabular}{llllllll}
\hline \hline $\begin{array}{l}\text { Project } \\
\text { Owner }\end{array}$ & $\begin{array}{l}\text { Bid at a fair } \\
\text { price }\end{array}$ & $\begin{array}{l}\text { Have good fi- } \\
\text { nancial skills }\end{array}$ & $\begin{array}{l}\text { Carry } \\
\text { work }\end{array}$ & $\begin{array}{c}\text { out } \\
\text { Prede- } \\
\text { termined } \\
\text { Technical }\end{array}$ & $\begin{array}{l}\text { Having } \\
\text { workforce }\end{array}$ & $\begin{array}{l}\text { Work } \\
\text { Time }\end{array}$ & $\begin{array}{l}\text { on } \\
\text { Priority Vec- } \\
\text { tor }\end{array}$ \\
\hline $\begin{array}{l}\text { Bid at a fair } \\
\text { price }\end{array}$ & 0.054 & 0.117 & 0.046 & 0.0805 & 0.0369 & 0.011 & 0.0576 \\
$\begin{array}{l}\text { Have good fi- } \\
\text { nancial skills }\end{array}$ & 0.0270 & 0.058 & 0.0763 & 0.0805 & 0.0491 & 0.015 & 0.0511 \\
$\begin{array}{l}\text { Carry out } \\
\text { work with }\end{array}$ & 0.270 & 0.178 & 0.2290 & 0.2013 & 0.2948 & 0.225 & 0.2328 \\
the right job \\
methodology
\end{tabular}

Consistency Index (CI) $=\frac{\lambda-n}{n-1}=\frac{6,389-6}{6-1}=0.07793$

(2)

Consistency Index $(\mathrm{CI})=\frac{C I}{R I}=\frac{0,07793}{1,64}=0.062822580645$
From the above calculation it is known that $\mathrm{CR}=$ $0.062822580645<0.1$ is Valid/Consistent.

G. Results of Weighting "Voice of Project Owner" Weighting the results of the criteria in the KDP "Voice of Customer" is in Table 7 below:

(3)

TABLE 4

RESULT OF WEIGHTING "VOICE OF CUSTOMER” PPK

\begin{tabular}{lll}
\hline \hline No & Criteria & Weight \\
\hline 1. & Carry out work in accordance with predetermined technical specifications & $36.12 \%$ \\
2. & Carry out work with the right job methodology & $23.28 \%$ \\
3. & Having workforce in accordance with the needs of the project & $19.39 \%$ \\
4. & Complete work on time & $10.33 \%$ \\
5. & Bid at a fair price & $5.76 \%$ \\
6. & Have good financial skills & $5.11 \%$ \\
\hline \hline
\end{tabular}




\section{H. Determining the Technical Response and Calculat- ing Weights}

Determination of technical response is carried out by conducting a Focus Group Discussion with electoral working groups, there are 9 members of the Election Working Group of which 9 Election Working Groups are members of the Construction Working Group who are also election working group leaders for packages below 2.5 billion.

The FGD was conducted by comparing the literature study that had been obtained with the evaluation method that had been done so far to make a technical response. from the list of "Voice of Project Owner" and stakeholders obtained from interviews.

After obtaining the level of importance of the criteria made by the AHP, each of these criteria is mapped to the technical response matrix by creating HOQ. After pairing from each technical response matrix at $\mathrm{HOQ}$, the weight of the matrix is calculated to obtain the overall priority of the Election Working Group's technical response.

TABLE 5

PRIORITIES FOR THE TECHNICAL RESPONSE OF THE WORKING GROUP

\begin{tabular}{|c|c|c|}
\hline 1 & $3.23 \%$ & The timetable for carrying out work is in accordance with the details of the Bill of Quantity \\
\hline 2 & $3.11 \%$ & The timetable for the execution of work does not exceed the period of execution of the work \\
\hline 3 & $3.06 \%$ & Get the support of the designated bank at least $10 \%$ of the value of the $\mathrm{OE}$ \\
\hline 4 & $2.62 \%$ & Evaluation of price fairness is done if the offer is $80 \%$ below $\mathrm{OE}$ \\
\hline 5 & $2.60 \%$ & Original Personnel Certificate and in accordance with the required field \\
\hline 6 & $2.58 \%$ & The unit price of the tool is reasonable for each major payment item \\
\hline 7 & $2.56 \%$ & The employment agreement between the business entity and core personnel is genuine \\
\hline 8 & $2.54 \%$ & $\begin{array}{l}\text { Has Construction Services Business License and Business Entity Certificate that are suitable and not } \\
\text { in the renewal period }\end{array}$ \\
\hline 9 & $2.49 \%$ & The ingredients offered are in accordance with the main job list \\
\hline 10 & $2.47 \%$ & Not declared bankrupt \\
\hline 11 & $2.45 \%$ & The unit price of materials is reasonable for each major payment item \\
\hline 12 & $2.44 \%$ & The working method is in accordance with the time of the implementation plan \\
\hline 13 & $2.33 \%$ & Quarry support for the main work (concrete work) has sufficient lifting equipment \\
\hline 14 & $2.31 \%$ & Quarry support for the main work is equipped with ISO 2001 quality management \\
\hline 15 & $2.31 \%$ & Quarry support for the main work is complemented by ISO 14001 environmental management \\
\hline 16 & $2.28 \%$ & Offer price can be accounted for \\
\hline 17 & $2.22 \%$ & Make real Project Ability Time calculations at the time of bidding \\
\hline 18 & $2.19 \%$ & Core personnel may only be placed in full on 1 job package location \\
\hline 19 & $2.19 \%$ & Schedule of using labor is arranged with a plan of needs every week \\
\hline 20 & $2.19 \%$ & The schedule for using the tool is arranged with a plan of needs every week \\
\hline 21 & $2.19 \%$ & Scheduled use of structured materials with planned needs every week \\
\hline 22 & $2.17 \%$ & Quarry support for the main job (concrete work) has its own batching plan \\
\hline 23 & $2.17 \%$ & The work method is related directly to the schedule of execution of work \\
\hline 24 & $2.17 \%$ & Quarry support for main jobs (concrete work) has sufficient stockpiling \\
\hline 25 & $2.11 \%$ & The fair wage unit price is based on the Surabaya City Regional Minimum Wage \\
\hline 26 & $2.09 \%$ & The material component for the main work material has a clear quarry source \\
\hline 27 & $2.08 \%$ & Schedule for using tools, materials and personnel connected to a master schedule \\
\hline 28 & $2.08 \%$ & Complete the previous project with the percentage of work completed $100 \%$ \\
\hline 29 & $2.05 \%$ & The procedure for carrying out work can be technically accountable \\
\hline 30 & $2.05 \%$ & The work method describes the material requirements \\
\hline 31 & $2.00 \%$ & The timetable for implementing the worksheet contains the weight of the work \\
\hline 32 & $1.81 \%$ & $\begin{array}{l}\text { Core personnel who have been determined at least have } 3 \text { years experience in working on similar } \\
\text { projects }\end{array}$ \\
\hline 33 & $1.78 \%$ & Has no debt to the Quarry before the auction year \\
\hline
\end{tabular}


TABLE 5

CONTINUE

\begin{tabular}{lll}
\hline \hline 34 & $1.78 \%$ & The quantity of material according to the coefficient in unit price analysis \\
35 & $1.74 \%$ & Quarry support for the main job is complemented by prices \\
36 & $1.69 \%$ & Assessing fair prices without taking into account profits \\
37 & $1.66 \%$ & The working methods of supporting work can be technically justified \\
38 & $1.53 \%$ & The Project Manager and site manager are the company's core personnel and are contained in official \\
& & company documents \\
39 & $1.44 \%$ & The wage quantity is in accordance with the coefficients in the unit price analysis \\
40 & $1.44 \%$ & Have company audited financial statements every year \\
41 & $1.28 \%$ & Quarry support for the main job (concrete work) has a sufficient stacking field \\
42 & $1.28 \%$ & Quarry support for the main work (concrete work) has a good transport fleet \\
43 & $1.27 \%$ & The working method describes the needs of the tool \\
44 & $1.23 \%$ & The sequence stage of the work is clearly illustrated from beginning to end \\
45 & $1.23 \%$ & The work method describes the needs of personnel \\
46 & $1.17 \%$ & Quarry support for main jobs (concrete work) has a good curring system \\
47 & $1.17 \%$ & Quarry support for the main work (concrete work) is equipped with a recap of material requirements \\
48 & $1.16 \%$ & Quantity of tool according to coefficient in unit price analysis \\
49 & $1.04 \%$ & Social Security Administrator contribution report for core project personnel is complete \\
50 & $1.01 \%$ & Contains background, purpose, purpose, location and scope of work \\
\hline \hline
\end{tabular}

To facilitate the application of technical response priorities to the "Voice of Project Owner" when evaluating tender documents, and to facilitate the playing frame of thinking throughout the Construction Selection Working Group in conducting evaluations, a software prototype was made.

\section{Software/Application Prototype}

The purpose of making this application is as a support system for making decisions and helping the Election Working Group get an assessment on each offer in accordance with the weight calculated/formulated, and each member of the Election Working Group has the same standard or standard without evaluating one of the criteria which needs to be considered in assessing the contractor's offer.

\section{STUDY CASE}

This Paper used the drainage work package of Jl.Wonorejo XXXX . The implementation of the work was delayed and many obstacles faced by the PO in the field, while the project data was as follows:

- Value of Owner Estimate (OE) Rp. 474,658,582.00

- The auction will be held on August 15, 2018 at the XXIII round auction

- There are 9 bidders, namely: CV. AS, CV. JW, CV.AMK, CV.APM, CV.GK, CV. CKM, CV. PJA, CV. RJ, CV. WA

- With each bid at a price CV. AS = Rp. 389,588.00.00; CV. JW
= Rp. 406,428,000.00; CV. AMK = Rp. 407,760,601.00; CV. $\mathrm{APM}=$ Rp. 465,760,601.00 ; CV. GK = Rp.465,942,816.00 ; CV. PJA = Rp. 453,298,761.00; CV. RJ = Rp.439,469,000.00; CV. WA = Rp. 426,858,533.00

- In this construction work package the Election Working Group wins the CV. AJ as a contractor selected to work on.

The results of the tender evaluation attached above will be compared to the results of the Election Working Group's decision made using evaluations in the application, whether the same value is obtained, or different, at what price, and whether the winning tender document has considered the PO Voice in the next section.

\section{A. Evaluation of Construction Tender Participant using the Application}

From the software application, it can be seen the final value of CV. The US is 5,659, the next step is to enter the whole value of the 8 other construction services business entities, which will then get a total value recap from 8 other service providers, then rank the total value of the service providers from the lowest to the highest consideration by the Election Working Group before the bid price is announced, if there are criteria that are considered 0 or there are no evaluation criteria, the construction service provider is considered to be dead, because it does not meet several evaluation criteria. 
SAE-JAK

\begin{tabular}{|c|c|c|c|c|c|c|c|c|c|c|c|c|c|c|c|c|c|c|c|c|}
\hline \multicolumn{4}{|c|}{ + Tambah Bodan Usaha } & & & \multicolumn{3}{|c|}{ A Mapus Semus Data } \\
\hline & $10 \cdot$ entries & & & & & & & & & & & & & & & & seer & & & \\
\hline No & $\mid \begin{array}{c}\text { BADAN } \\
\text { BSAAA } \\
\text { USA }\end{array}$ & TOTAL & $\begin{array}{l}\text { (Bobot } \\
= \\
=0.025)\end{array}$ & skor & $\begin{array}{l}\text { (Bobot } \\
\\
0.021)\end{array}$ & Skor & $\begin{array}{l}\text { (Bobot } \\
\bar{z} \\
0.017)\end{array}$ & skor & $\begin{array}{l}\text { (Bobot } \\
\overline{0} \\
0.023)\end{array}$ & skor & $\begin{array}{l}\text { (Bobot } \\
\stackrel{\text { (I) }}{0.023)}\end{array}$ & Skor & $\begin{array}{l}\text { (Bobot } \\
\bar{\Xi} \\
0.0222)\end{array}$ & skor & $\begin{array}{l}\text { (Bobott } \\
\bar{~} \\
0.023)\end{array}$ & skor & $\begin{array}{l}\text { (Bobot } \\
= \\
0.013)\end{array}$ & skor & $\begin{array}{l}\text { (Bobot } \\
\stackrel{\text { (I.012) }}{\text { o. }}\end{array}$ & skot \\
\hline 1 & $\begin{array}{l}\text { CV.AS } \\
\text { Uboshisiai }\end{array}$ & 5,659 & 9 & 0.225 & 3 & 0.063 & 9 & 0.153 & 9 & 0.207 & 9 & 0.207 & 9 & 0.199 & , & 0.207 & 9 & 0.117 & 9 & 0.10 \\
\hline 2 & $\begin{array}{l}\text { C. AMK } \\
\text { Uabohniliai }\end{array}$ & 6,451 & 9 & 0.225 & 9 & 0.189 & 9 & 0.153 & ? & 0.207 & 9 & 0.207 & 9 & 0.199 & 9 & 0.207 & 9 & 0.117 & 3 & 0.0 \\
\hline 3 & $\begin{array}{l}\text { CV.APM } \\
\text { Ubahneilai }\end{array}$ & 6,649 & 3 & 0.075 & 9 & 0.189 & , & 0.153 & ? & 0.207 & 9 & 0.207 & 9 & 0.198 & 9 & 0.207 & 9 & 0.117 & , & 0.1 \\
\hline 4 & $\begin{array}{l}\text { Qv, GK } \\
\text { Ubashiliai }\end{array}$ & 5,965 & 9 & 0.225 & 3 & 0.063 & 3 & 0.051 & 3 & 0.069 & 3 & 0.069 & 3 & 0.066 & 9 & 0.207 & 3 & 0.039 & 3 & 0.0 \\
\hline 5 & 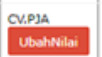 & 7,333 & 3 & 0.075 & 9 & 0.189 & 1 & 0.017 & 9 & 0.207 & 9 & 0.207 & 9 & 0.198 & 9 & 0.207 & 9 & 0.117 & 9 & 0.1 \\
\hline 6 & $\begin{array}{l}\text { ON. N } \\
\text { Ubatheliai }\end{array}$ & 5,623 & 3 & 0.075 & 1 & 0.021 & 9 & 0.153 & 9 & 0.207 & 9 & 0.207 & 9 & 0.199 & 9 & 0.207 & 9 & 0.117 & 9 & 0.1 \\
\hline 7 & Q. wa & 7,132 & 9 & 0.225 & 9 & 0.189 & 9 & 0.153 & 9 & 0.207 & 9 & 0.207 & 9 & 0.199 & 9 & 0.207 & 9 & 0.117 & 9 & 0.10 \\
\hline
\end{tabular}

Fig. 4. Prototype software

TABLE 6

SIMULATION OF COMPARISON OF ASSESSMENT OF ELECTION WORKING GROUPS

\begin{tabular}{lllll}
\hline \hline Contractors & Manual Assesment & Bid Price & Application ranking & Application Assestment \\
\hline CV. AS & Tender Winner & Rp. 389.588.00,00 & 5 & 5,659 \\
CV. AMK & Reserve 1 & Rp. 407.760.601,00 & 3 & 6,451 \\
CV.APM & Not Rated & Rp.465.760.601,00 & 2 & 6,649 \\
CV.GK & Not Rated & Rp.465.942.816,00 & 4 & 5,965 \\
CV.PJA & Not Rated & Rp.453.298.761,00 & 1 & 7,333 \\
CV.RJ & Not Rated & Rp.439.469.000,00 & 6 & 7,132 \\
CV.WA & Fall & & Does Not Pass Personnel Evaluation & 7,411 \\
CV. JW & Fall & & Not Graduating Administration & 0 \\
\hline \hline
\end{tabular}

TABLE 7

TENDER PROTOTYPE SOFTWARE EVALUATION RESULTS

\begin{tabular}{llllll}
\hline \hline Contractors & Manual Rank & Aplication Rank & Application Assestment & Bid Price & Manual Assesment \\
\hline CV.PJA & 5 & 1 & 7,333 & Rp.453.298.761,00 & Not Rated \\
CV.APM & 6 & 2 & 6,649 & Rp.465.760.601,00 & Not Rated \\
CV. AMK & 2 & 3 & 6,451 & Rp.407.760.601,00 & Reserve 1 \\
CV.GK & 4 & 4 & 5,965 & Rp.465.942.816,00 & Not Rated \\
CV. AS & 1 & 5 & 5,659 & Rp. 389.588.00,00 & Not Rated \\
CV.RJ & 3 & 6 & 7,132 & Rp.439.469.000,00 & Not Rated \\
\hline \hline
\end{tabular}

From the simulation above, it can be seen that, the limited assessment of the Election Working Group only on the 3 lowest bidders has caused the Election Working Group to be unable to assess the offers of the other 4 contractors. Whereas in the simulation conducted by the application, it can be seen that with the offer price ranked 5 th, out of a total of 8 offers that passed the administrative selection, CV. PJA has the highest application rating of 7.333 from the highest score of 9 which connects the level of conformity of the technical response of the Election Working Group to the Project
Owner Vote, while the CV. AS won as the winner of the tender with the lowest bid price with an application value of 5.659 , is ranked 5th from the application system .

It can be interpreted that in this choice, the Election Working Group paid little attention to the wishes of Project Owner as in winning the tender. The lowest price assessment that does not represent "Voice of project owner" is still dominantly conducted by the Election Working Group. From table 4.2 can be seen if the consideration of the lowest price that still burdens the Election Working Group due to 
many factors $\mathrm{X}$, for example the objection factor that will be delivered by the lowest price candidate, the Election Working Group can choose CV. AMK, which is at the level of the second level, while in the application is in the third rank, which is more in favor of the voice of project Owner compared to CV.AS.

\section{CONCLUSION}

There are 5 "Voice Of Project Owner" criteria that should be used by the Election Working Group in evaluating the construction service provider tenders, the 5 criteria being responded with 50 technical responses whose relationships are described by the House of Quality matrix prototypekan in the form of a Construction Service Provider Application System (SAE-JAK) In the simulation results of the comparison of the decision on the selection of tender winners (contractors) conducted manually by the Election Working Group when compared with the decision on the selection of tender winners conducted using SAE-JAK, it can be seen that there are significant differences. Where the decision of the winner of the tender generated by the system designates the participant with the lowest bid price of 5 with the highest application value of 7.333 or $81 \%$ the decision made is in accordance with the "Voice of Project Owner", while the Election Working Group decision is manually prioritized the lowest bid price with an application value of 5.659 or around 62\% using "Voice of Project Owner", this error can occur because the Election Working Group only evaluates the tender document to the 3 lowest bids so the 4th bidder with the best application value is not assessed.

The Construction SAE-JAK is expected to be able to assist the working group to make decisions that pay attention to "Voice of Project Owner" so the implementation and supervision of work can run more easily, SAE-JAK can also help woking group to evaluate more, and base decision preferences not only on the lowest prices.

\section{REFERENCES}

[1] D. Singh and R. L. Tiong, "A fuzzy decision framework for contractor selection," Journal of Construction Engineering and Management, vol. 131, no. 1, pp. 62-70, 2005. doi: https://doi.org/10.1061/(asce)0733-9364(2005)131:1(62)

[2] E. B. Nejad and R. A. Poorsabzevari, "A new method of winner determination for economic resource allocation in cloud computing systems," Journal of Advances in Technology and Engineering Research, vol. 2, no. 2, pp. 12-17, 2016. doi: https://doi.org/10.20474/-jater2.1.3

[3] P. Treshani and K. G. A. S. Waidyasekara, "Sustainable responses to minimise recessionary effects in the Sri Lankan construction industry," International Journal of Technology and Engineering Studies, vol. 1, no. 3, pp. 87-97, 2015. doi: https://doi.org/10.20469/ijtes.40004-3

[4] N. El-Sawalhi, D. Eaton, and R. Rustom, "Contractor pre-qualification model: State-of-the-art," International Journal of Project Management, vol. 25, no. 5, pp. 465-474, 2007. doi: https://doi.org/10.1016/j.ijproman.2006.11.011

[5] Z. Hatush and M. Skitmore, "Contractor selection using multicriteria utility theory: An additive model," Building and Environment, vol. 33, no. 2-3, pp. 105-115, 1998. doi: https://doi.org/10.1016/s0360-1323(97)00016-4

[6] J. Dai and J. Blackhurst, "A four-phase AHP-QFD approach for supplier assessment: A sustainability perspective," International Journal of Production Research, vol. 50, no. 19, pp. 5474-5490, 2012. doi: https://doi.org/10.1080/00207543. 2011.639396

[7] J. A. Carnevalli and P. C. Miguel, "Review, analysis and classification of the literature on QFD-types of research, difficulties and benefits," International Journal of Production Economics, vol. 114, no. 2, pp. 737-754, 2008. doi: https: //doi.org/10.1016/j.ijpe.2008.03.006

[8] P. Chuang, "Combining the analytic hierarchy process and quality function deployment for a location decision from a requirement perspective," The International Journal of Advanced Manufacturing Technology, vol. 18, no. 11, pp. 842-849, 2001. doi: https://doi.org/10.1007/s001700170010

[9] O. S. Vaidya and S. Kumar, "Analytic hierarchy process: An overview of applications," European Journal of Operational Research, vol. 169, no. 1, pp. 1-29, 2006. doi: https://doi.org/10.1016/j.ejor.2004.04.028

[10] W. Ho, T. He, C. K. M. Lee, and A. Emrouznejad, "Strategic logistics outsourcing: An integrated QFD and fuzzy AHP approach," Expert Systems with Applications, vol. 39, no. 12, pp. 10 841-10 850, 2012. doi: https://doi.org/10.1016/j. eswa.2012.03.009

[11] W. Ho, "Integrated analytic hierarchy process and its applications-a literature review," European Journal of Operational Research, vol. 186, no. 1, pp. 211-228, 2008. doi: https://doi.org/10.1016/j.ejor.2007.01.004 
[12] A. Bhattacharya, B. Sarkar, and S. K. Mukherjee, "Integrating AHP with QFD for robot selection under requirement perspective," International Journal of Production Research, vol. 43, no. 17, pp. 3671-3685, 2005. doi: https://doi.org/ 10.1080/00207540500137217

[13] M. S. Ozcoban, S. G. Durak, T. O. Acar, G. T. Demirkol, S. O. Celik, and N. Tufekci, "Evaluation of clay soils' permeability: A comparative study between the natural, compacted, and consolidated clay soils," Journal of Advances in Technology and Engineering Research, vol. 3, no. 5, pp. 184-191, 2017. doi: https://doi.org/10.5004/dwt.2017.21014

[14] L. K. Chan and M. L. Wu, "Quality function deployment: A literature review," European Journal of Operational Research, vol. 143, no. 3, pp. 463-497, 2002. doi: https://doi.org/10.1016/s0377-2217(02)00178-9

[15] M. Hua Lu, C. N. Madu, C. H. Kuei, and D. Winokur, "Integrating QFD, AHP and benchmarking in strategic marketing," Journal of Business and Industrial Marketing, vol. 9, no. 1, pp. 41-50, 1994. doi: https://doi.org/10.1108/ 08858629410053470

[16] T. L. Saaty, Applications of Analytic Network Process in Entertainment. New York, NY: RWS Publications, 2009.

[17] J. Rahardjo, R. Yustina, and R. E. Stok, “Penerapan multi-criteria decision making dalam pengambilan keputusan sistem perawatan," Jurnal Teknik Industri, vol. 2, no. 1, pp. 1-12, 2004. doi: https://doi.org/10.14710/jati.12.2.127-136

[18] N. Bhushan and K. Rai, Strategic Decision Making: Applying the Analytic Hierarchy Process. New Dehli, India: Springer Science \& Business Media, 2007.

[19] G. Rajesh and P. Malliga, "Supplier selection based on AHP QFD methodology," Procedia Engineering, vol. 64, no. 6, pp. 1283-1292, 2013. doi: https://doi.org/10.1016/j.proeng.2013.09.209

[20] Y. Akao, "Development history of quality function deployment: The customer driven approach to quality planning and deployment," Japan Asian Productivity Organization, Minato, Tokyo, Techincal report, 1994.

[21] D. Gunther, "Quality function deployment-how to make QFD work for you," Insight, vol. 3, no. 2, pp. 55-56, 2000. doi: https://doi.org/10.1002/inst.20003255

[22] J. R. Hauser, "How puritan-bennett used the house of quality." Sloan Management Review, vol. 34, no. 3, pp. 61-71, 1993. doi: https://doi.org/10.1016/0737-6782(94)90020-5

[23] A. D. Cohen, Strategies in Learning and Using a Second Language. New York, NY: Routledge, 2014. 